\title{
In Crisis or Decline? Selecting Women to Lead Provincial Parties in Government
}

\author{
By Melanee Thomas \\ Associate Professor \\ Department of Political Science \\ University of Calgary \\ 2500 University Drive NW \\ Calgary, AB T2N 1N4
}

\begin{abstract}
The majority of Canada's women premiers were selected to that office while their parties held government. This is uncommon, both in the comparative literature and amongst premiers who are men. What explains this gendered selection pattern to Canada's provincial premiers' offices? This paper explores the most common explanation found in the comparative literature for women's emergence as leaders of electorally competitive parties and as chief political executives: women are more likely to be selected when that party is in crisis or decline. Using the population of women provincial premiers in Canada as case studies, evidence suggests 3 of 8 women premiers were selected to lead parties in government that were in crisis or decline; a fourth was selected to lead a small, left-leaning party as predicted by the literature. However, for half of the women premiers, evidence of their party's decline is partial or inconclusive. As a result of this exploration, more research is required to draw generalizations about the gendered opportunity structures that shape how women enter (and exit) the premier's office in Canada.
\end{abstract}




\title{
In Crisis or Decline? Selecting Women to Lead Provincial Parties in Government
}

\begin{abstract}
The majority of Canada's women premiers were selected to that office while their parties held government. This is uncommon, both in the comparative literature and amongst premiers who are men. What explains this gendered selection pattern to Canada's provincial premiers' offices? This paper explores the most common explanation found in the comparative literature for women's emergence as leaders of electorally competitive parties and as chief political executives: women are more likely to be selected when that party is in crisis or decline. Using the population of women provincial premiers in Canada as case studies, evidence suggests 3 of 8 women premiers were selected to lead parties in government that were in crisis or decline; a fourth was selected to lead a small, left-leaning party as predicted by the literature. However, for half of the women premiers, evidence of their party's decline is partial or inconclusive. As a result of this exploration, more research is required to draw generalizations about the gendered opportunity structures that shape how women enter (and exit) the premier's office in Canada.
\end{abstract}

\section{Introduction ${ }^{1}$}

Worldwide, women are typically less likely than men to serve as chief political executives - that is, as presidents, premiers, and prime ministers (Jalalzai, 2013). This pattern also holds in Canada: despite recent parity cabinets in the federal and some provincial governments, women typically comprise less than one-third of cabinet ministers at any level of government (Trimble, Tremblay, and Arscott, 2014), and between 2002 and 2008, no women served as premier or prime minister at the provincial or federal level. Similarly, women in municipal politics are less likely to be mayors than are men (Tolley, 2011).

Given this, it is noteworthy how, starting in 2010, a considerable number of women were selected to serve as provincial premiers. Starting in 1991, eight women have served in this office; of them, six were made premier first through an inter-election, party-based appointment while their parties held government. During the same period, 50 men were selected premier, and a majority of them were made premier first through general election. What explains this gendered pattern?

One explanation is that women are more likely than men to be selected to lead parties in government that are in crisis or decline. This would be in keeping with what is known about women and political party leadership, both in Canada and in the comparative literature (O'Neill and Stewart, 2009; Cross and Blais, 2012; Beckwith, 2015). It also fits with the fact that several of the women premiers exited the office relatively quickly after they entered it. In addition to this, to date, no political party led by a woman in Canada has decisively won more than one election. Thus, we are presented with an interesting pattern: women are selected directly to the premier's office through a party leadership contest, sometimes lead their parties to majority mandates, but then do not have the support to stay in office for an entire term, or to be re-elected again. The result is that by the end 2017, only two woman

${ }^{1}$ I would like to thank David Stewart, Amanda Bittner, David McGrane, Graham White, and the anonymous reviewers for comments on a previous draft of this paper. My thanks, too, to John Santos for his research assistance. 
premiers hold their own electoral mandates (Wynne and Notley), and neither is expected to be easily re-elected.

This pattern of party-based selection and quick exits raises a host of research questions about women's entrances and exits as premiers, as well as their leadership styles, influence on policy, and media, public, and internal party reactions to their presence. This paper contributes to a larger research agenda by examining one small facet of gender and the political executive in Canada: the contexts through which women are first selected to the premier's office. It uses the most common explanation found in the literature for women's emergence as leaders of electorally competitive parties as a starting point: that the parties are in crisis or in decline (O'Brien, 2015; Beckwith 2015). ${ }^{i}$ Results suggest, that contrary to expectations, evidence supports this explanation for 3 of the 8 women premiers, and that a fourth is explained by existing literature on gender and party leadership. However, for half of the women that have served as provincial premiers, evidence of their party's decline is at best partial or inconclusive. This highlights gender and the premier's office as a fruitful avenue for future research.

\section{Why Premiers?}

Premiers are powerful actors in the Canadian political system. Provinces are responsible for key programmes associated with the welfare state, including health care, education, welfare, and child care, as well as all municipalities and major metropolitan centres. Provincial governments in Canada have a strong presence, considerable jurisdictional control and fiscal capacity, as well as the ability to design and deliver a large number of government services (Simeon, 2002; 0'Neill and Stewart, 2009).

In addition to this, provincial legislatures in Canada, like their federal counterpart, are "not [systems] of checks and balances, but of fused, concentrated, centralized power," where power rests in the political executive rather than the legislature (Franks, 1987: 265; Russell, 2008). At the federal level, this is characterized as "prime ministerial government," where the chief executive dominates cabinet (Savoie, 1999; 2003). This pattern is replicated and exacerbated at the provincial level. Comparatively speaking, "even by Westminster standards, Canadian first ministers wield exceptional power," due, in part, to the absence of institutional constraints within legislatures that are found in other cabinet-parliamentary systems (White, 2005: 77). This leads White to conclude that "Provincial government is indeed premiers' government" (ibid.). Add to this the electoral significance of party leaders for vote choice in Canada (Gidengil et al., 2012; see also Poguntke and Webb, 2005; Webb and Poguntke, 2013), and it is clear that provincial premiers are some of the most important actors in Canadian politics.

Expanding this analysis to provinces adds useful information for gender and politics research. To date, 12 women have served as chief political executives in Canada and the overwhelming majority $(\mathrm{N}=11)$ are found at the subnational level. This would be missed if, like most studies of chief executive offices, we focused solely on the 
national level (see, for example, 0'Brien, 2015; Jalalzai, 2008; 2011). This study restricts the analysis to women in provincial premier's offices, given the constitutional differences between the provinces and the territories. ${ }^{\text {ii Studying }}$ women in provincial premier's office represents one of, if not the best way to assess women's access to chief political executive positions in Canada.

\section{Who are the Women in the Provincial Premier's Office?}

Table 1 shows the women who have served as provincial premiers in Canadian history, presented in the order in which they were sworn into office. The first woman provincial premier, Rita Johnston, was a clear sacrificial lamb, as will be shown below, as her party was in a clear crisis when she was selected leader. The competitive position of the second, Catherine Callbeck of Prince Edward Island (PEI), appears very different: Callbeck was selected leader of a party in government, won a majority mandate in a subsequent general election, and then resigned before the end of that term.

[Table 1 about here.]

The bulk of women provincial premiers have been selected more recently. Of the six selected since 2010, four were first selected premier through internal party mechanisms, and three went on to lead their parties to majority election victories. Both Marois and Notley were first selected premier through general elections. Though these more recently selected premiers appear to be more stable and powerful than did Johnston, none have yet to secure more than one general election victory. Dunderdale and Redford resigned in early 2014, while Marois led her party to its worst electoral defeat since the late 1970s. Clark technically led her party to re-election, but the election returned a minority legislature, and she did not secure the confidence of the legislative assembly.iii

\section{Women, Party Leadership, and the Premier's Office}

Table 1 shows that six of the eight, or 75 per cent of the women who have served as a provincial premier were first selected directly to the office through internal party mechanisms. This is striking for two reasons. First, this pattern is different from men's. Excluding interim party leaders, 50 men have served as premiers in Canada since 1991.iv Of these, 56 per cent were first selected provincial premier through general elections. This suggests the path to the premier's office in Canada is gendered: men who become provincial premier are most likely to do so through general election, but women who become provincial premier are, to date, most likely to do so through internal party mechanisms.

Second, comparative evidence shows that men's path to provincial premier's office is the international norm. Most political executive offices in parliamentary democracies are populated, at least for the first time, following a general election, rather than internal party processes between elections. One of the most comprehensive studies of party leadership selection in parliamentary democracies 
does not address when and why individuals may be selected for the dual role of party leader and chief political executive at the same time (see Cross and Blais, 2012). Certainly, gendered analyses of women prime ministers highlight the importance of first being selected party leader, but even in these instances, the women in question (Angela Merkel, Margaret Thatcher) are first selected as party leader and then subsequently become prime minister through a general election (Beckwith, 2015). This suggests that women's paths to the premier's office in Canada are different than men's and also, potentially, from the comparative norm.

Given this, it is perhaps unsurprising that even less is known about the gendered aspects of selection to the dual role of party leader and chief executive. Most research investigating gender and political careers focuses on women's presence and participation in legislatures (Kathlene, 1994; Trimble and Arscott, 2003; Childs and Krook, 2008). Studies on women in provincial cabinets in Canada suggest that the most important factor leading to the appointment of women to cabinet is the proportion of women in the governing party (Studlar and Moncrief, 1997, but see also O'Brien et al., 2015). Comparative research shows that women are more likely to serve as chief political executives with power is shared or constrained (Jalalzai, $2008 ; 2013)$, and that women-led governments do not necessarily promote women into cabinet (O'Brien et al., 2015). And, studies conclude that gender stereotypes have negative effects on women's ability to be directly elected to executive office (Huddy and Terkildsen, 1993; see also Fox and Oxley, 2003; Streb et al. 2008).

Women's selection to the dual role of party leader and premier is also atypical because most party leaders are not women. Between 1965 and 2008, only eight per cent of newly elected party leaders in parliamentary democracies were women (Cross and Blais, 2012). Women's leadership numbers are low because minor parties outside of government are typically more likely to select women leaders than are major parties (0'Brien, 2015). 0'Neill and Stewart (2009) note that in Canada between 1980 and 2005, 67 per cent of male leaders, but only 12 per cent of female leaders headed major, electorally competitive parties. By 2005, "only one of the 21 women elected to lead a [provincial] political party in Canada has gone on to win an election" (0'Neill and Stewart, 2009: 749). This suggests that the legislative and electoral contexts faced by women in general, and female party leaders in particular, are hostile. Other Canadian scholars note that women lead "electorally decimated and moribund parties," (Trimble and Arscott, 2003: 77). Prior to 2010, only Catherine Callbeck had been selected leader for an electorally competitive party at the provincial level (Bashevkin, 2009); it was not until 2011 that a woman was selected party leader through a universal vote of party members (see Cross and Blais, 2012).

This literature suggests, then, that the women in the premier's office are different from their male peers in Canada as well in other parliamentary democracies.

\section{When might women be selected as party leaders and/or provincial premiers?}


Research shows that the higher the political office, the fewer women will be found in them, especially when those offices are safe, secure, and electorally viable (Bashevkin, 1993; 2009). This suggests that the most likely explanation for women's selection as party leader/premier rests with party crisis and decline. Comparative research shows that parties that are losing support or are in crisis are more likely to select women leaders than are parties with stable support (O'Brien, 2015; Beckwith, 2015).

Crisis and decline create strategic contexts that remove men who might otherwise contest party leadership. Women thus become competitive when they otherwise might not be. As strategic actors, women may see crisis or decline as producing a moment where they might be able to secure leadership they may otherwise not have access to (see Beckwith, 2015). A similar argument posits that women might be preferred over men as leaders when the crisis or decline was the result of men's leadership failures (Bruckmüller and Branscombe, 2010). Women may be stereotyped as more moral or less corruptible than men (Fridkin Kahn, 1994; Huddy and Capelos, 2002), making them potentially more appealing to the party selectorate and, in theory, to the electorate overall.

What does it mean for a party to be in crisis or decline? Crisis can be defined, at least in part, by electoral loss (Beckwith, 2015). However, losing an election alone does not mean a party is in crisis. Crisis implies an acute, intense, time-sensitive period of difficulty for a party or a government. Angela Merkel could be characterized as strategically using crisis to secure her party's leadership. After her party, the Christian Democratic Union (CDU), decisively lost the 1998 elections, the party became embroiled in a corruption scandal. These two factors ensured that men who would normally have contested the leadership of the CDU were removed from serious consideration, creating space for Angela Merkel to successfully seek leadership of the party (ibid.). Thus, crisis can emerge from significant, protracted electoral loss, major scandal, or a series split within a party.

Decline, by contrast, is perhaps best characterized as more a more gradual loss of support. A party, or a party in government that is in decline is on an unfavourable electoral trajectory, and may lose both votes and seats in the election preceding the leadership contest (O'Brien, 2015; O'Neill and Stewart, 2009). Here, the British Conservatives' experience leading to Margaret Thatcher's selection as party leader might be best characterized as decline. Then-leader Edward Heath had been party leader since 1965. The party had lost two elections in 1974, creating an appetite for a challenge to Edward Heath's leadership. This may have been, at least in part, due to the perception that Heath's leadership was tired, or unable to respond effectively to the party's perceived decline. Importantly for Thatcher, some contenders were removed from consideration, either by earlier scandal or by not coming forward to challenge Heath's leadership, as or before Thatcher did. Other men only entered the contest after Thatcher's challenge removed Heath; despite this, Thatcher successfully secured a majority of votes on the second ballot (Beckwith, 2015).v 
Measuring a party's gradual decline is far more challenging than identifying when a party is in acute crisis. It will be clear, for example, if a party spectacularly loses an election (and does not recover), or is embroiled in a serious scandal. By contrast, the best way to measure decline - the slow(er) loss of strength and support - is far less clear. Given this and the fact that 75 per cent of women enter the premier's office through an internal party process rather than a general election, the bulk of the empirical tests that follow focus on whether their parties were in decline when women were selected as leader/premier.

\section{Measuring Decline}

As noted above, a party in decline is one that has an unfavourable electoral trajectory. Unlike a party in crisis, parties in decline could experience attrition in their support gradually, or present weaknesses that are seen as harbingers of expected electoral defeat. Given this, accurately measuring the stability of a party's support is especially important.

In this article decline is operationalized in five ways. For each, decline exists if a party's support appreciably drops; in the absence of clear evidence of that drop, the party's support could be characterized as stable. In order to avoid ex post facto logic, evidence must show that this decline precedes each woman's selection as party leader/premier; decline that occurs after women's selection cannot be contributing factor in their selection as leader/premier.

First, the party's performance in the election immediately prior to a woman's selection as leader/premier is assessed. Parties in decline would lose votes, seats, or both. This measurement of decline is available for every provincial party that selected a woman as leader/premier, and is presented in Table 2 .

The second measure is party support stability. This is a rigorous measure that combines information from two past elections to assess how stable a party's support is over time, making it an ideal measure to diagnose whether a party is in decline. Its application at the federal level between 2004 and 2008 identified considerable declines in Liberal Party of Canada support well in advance of the party losing seats it had once identified as safe (Bodet, 2013; Thomas and Bodet, 2013). The difficulty with this measure is that it can only be generated when district boundaries are stable across time and/or elections are held using single member districts. This is problematic for BC and Newfoundland and Labrador, vi as well as PEI.vii Given this, the strongholds/battlegrounds measure is calculated for Alberta in 2008 (prior to Redford's selection as party leader/premier) and Ontario in 2011 (before Wynne's selection as party leader/premier, see Table 3).

Because general elections occur in the provinces every four to five years, a party's support at the previous election might not identify erosion in its support, particularly if the party remains in government. In light of this, by-election results and contributions to party finances are used as the third and fourth indicators 
respectively. By-election results may highlight how voters feel about a party in government overall (see Loewen and Bastien, 2010); for example, if a party in government loses by-elections in electoral districts it would typically win, this might suggest the party is in decline. All by-elections held between the previous election and the leadership selection for each woman premier are included here (Table 4). Similarly, though most of the research on campaign and party finance in Canada focuses on federal politics and parties (see Cross, 2004; Scarrow, 2007; Coletto, Jansen, and Young, 2011), Canada's provincial political parties also finance themselves through contributions from individuals and businesses. This suggests that parties in decline should report lower levels of contributions in the years prior to the selection of a new leader. Contributions data are publicly available for parties selecting a woman as leader/premier since 2010, and are presented in Table 5.

The fifth and final way decline is measured is through publicly available opinion polls. viii Past election results could underplay the speed with which a party in government loses support. Given this, public opinion polls are a logical option to capture any shifts in a party's support that occur after a general election, but before a leadership contest. The veracity and quality of these polls is secondary, as these polls were published and formed the narrative around each political party and their

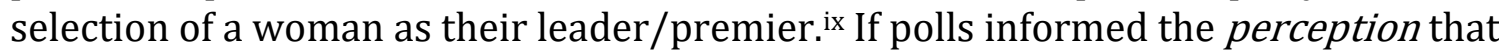
the party to be in decline when a woman was selected as party leader/premier, this could be taken as evidence that a woman was selected leader and premier of a party in decline (Figures 1-4).

\section{Analysis}

\section{Parties in Crisis}

Of the eight women listed in Table 1, two were selected to lead parties in crisis: Rita Johnston, and Pauline Marois. Each became party leader during an acute period of difficulty for her party.

In 1991, Bill Vander Zalm resigned as BC premier and Social Credit leader after he was charged with criminal breach of trust relating to the sale of some of his property (Paikin, 2003; CBC Digital Archives, 2014). This scandal produced an acute crisis for the BC Social Credit party. Johnston faced no male challengers, and narrowly beat another woman (Grace McCarthy) for the party leadership (McElroy, 2017). She was in office for only seven months before her party suffered a devastating electoral defeat from which it has never recovered (Table 1; Elections $\mathrm{BC}, 2014 \mathrm{a}$ ). Because of this, Johnston is perhaps best described as a sacrificial lamb for a party in crisis.

Similarly, the PQ was in crisis when it selected Pauline Marois to be its leader, though for different reasons. Marois' successful bid for the PQ leadership built on its 2007 electoral loss. ${ }^{x}$ This election marks the third in a row where the PQ lost support. In 1998, the party won government but lost the popular vote. In 2003, the party lost government and nearly 10 percentage points in popular support. By 2007, the party lost 5 more points, securing less than 30 per cent of the popular vote, and 
finishing third for the first time since forming government in 1976. The scope and protracted nature of this loss creates the crisis that precedes Marois's selection as leader. In keeping with the comparative literature, Marois was not challenged by competitive men, ran unopposed, and was acclaimed leader. ${ }^{\mathrm{xi}}$

Though Marois and Johnston fit with the comparative literature on gender and party leadership, they remain distinctive amongst women premiers in Canada. Most were selected leader, and by extension, provincial premier partway through an existing electoral mandate in the absence of an obvious scandal or crisis. The question remains whether these women were selected to lead parties in decline.

\section{Which Parties are in Decline?}

Data exist to test the assertion that women are more likely to be selected party leader/premier when their party is in decline for four women in the premiers' offices: Kathy Dunderdale, Christy Clark, Alison Redford, and Kathleen Wynne. Where possible, data are also reported for Catherine Callbeck.xii

Table 2 shows the change in the change in party vote and seat share in the election leading up to, and following a woman's simultaneous selection as party leader and premier.xii

\section{[Table 2 about here.]}

Most parties do not appear to be in decline the election prior to selecting a woman as leader and premier simultaneously. Instead, support for most of these parties appears to be stable or increasing. The one exception to this appears to be Kathleen Wynne in Ontario. Though the Ontario Liberal Party's support slipped by less than 5 percentage points in 2011 over 2007, the party lost 18 seats.

What is perhaps more telling is that nearly every party that simultaneously selected a woman as party leader and premier lost votes in the election following her selection. Some of these losses are devastating, as is the case with Johnston, while others appear to be moderate, as is the case with Dunderdale and Redford. What remains unknown from Table 2 is whether the selection of a woman as party leader/premier was the result of a shorter-term decline, or the result of the woman's failures while in office. Still, Table 2 shows that most of these parties were not in decline the election before they selected a woman leader/premier.xiv

Table 3 presents results from the second measure of party decline: party support stability. This measure uses information from the previous two elections to assess how many strongholds a party had. A party in a long, slow decline may be able to win a majority mandate even while its support is eroding. This measure speaks directly to how confident a party in government could be about retaining power at the next election, based on the long-term stability of its support.

[Table 3 about here.] 
Prior to Redford's selection as party leader, her party had 54 strongholds. This means that, based on the past two elections, the Alberta PCs could expect that their party would win 65 per cent of the seats available in the legislature. A party in decline could not have so many strongholds, suggesting that the Alberta PCs were not in long(er) term decline when Redford was selected as leader.

Table 3 suggests the Ontario Liberals were less stable than the Alberta PCs when Wynne was selected leader. The Liberals held 47 strongholds, representing 44 per cent of the Ontario legislature. Though this the most strongholds of any party at the time, the Liberals would still need to win 7 of the 23 battlegrounds to form a majority government. This is a more tenuous position for an incumbent party in government, and when coupled with the losses in the election prior to Wynne's selection, it suggests the Liberals may have been experiencing longer-term decline before Wynne's selection.

More time-sensitive measures can show if parties in government experience a shorter-term decline. Table 4 shows the number of by-elections held between the previous election and the year each woman was selected as party leader/premier. One challenge is that in most provinces, only one or two by-elections are held, making it difficult to identify a pattern. The Alberta PCs lost one by-election to the opposition Wildrose prior to Redford's selection as PC leader. A post-hoc rationale may place a great deal of importance on a single by-election loss; placed appropriately in time order, though, this is weak evidence of a party in decline. Similar time order issues exist for the Ontario Liberals: though they did not lose seats in by-elections prior to Wynne's selection in February 2013, by September, the Liberals had lost 3 seats to opposition parties. This is more suggestive of decline, and matches the results found in Table 3. Newfoundland and Labrador's byelections suggest that the PCs had strong support prior to Dunderdale's selection.

[Table 4 about here.]

[Table 5 about here.]

Table 5 outlines financial contributions made to political parties which selected women as their leaders while they held government, and shows that none of these parties experienced consistent year-over-year declines in contributions in the three years prior to selecting women as leaders/premiers. Instead, the Newfoundland and Labrador PCs increased their contributions year over year prior to Dunderdale's selection. The other parties, though, show some decline in donations, though these are not steady or linear for any of the parties. Contributions to the BC Liberals increased by 52 per cent two years before Clark's selection, but then decreased by 23 and 3 per cent respectively. Similarly, contributions to the Alberta PCs increased in the two years prior to Alison Redford's selection, but decreased by 21 per cent the year she was selected leader/premier. Finally, the Ontario Liberals exhibited a sharp decline in contributions the year prior to Wynne's selection as leader, but then 
received more in contributions the year she was selected than they did in any of the previous three years. Again, this suggests the Ontario Liberals were a party in decline when Wynne was selected.

Though most parties posted declines in contributions prior to selecting women as leaders/premiers, Table 5 also shows that each party had considerable financial resources on hand. For example, though contributions to the Ontario Liberals were down prior to Wynne's selection, they still collected over $\$ 4$ million in contributions in 2012. Similarly, though donations were down by nearly $\$ 3$ million, the $\mathrm{BC}$ Liberals still collected over $\$ 9$ million in donations the year before Clark was selected. While it may be tempting to conclude from these contributions data that these parties exhibited some financial decline prior to selecting women as leaders and premiers, it would not be fair to claim that this decline was steady or consistent over time.

Finally, public opinion polls may be able to provide evidence that a party was in decline prior to selecting a woman as leader/premier. Certainly, publicly available polls are of varying quality, and many fail to accurately predict a party's genuine level of support. Despite this, political media coverage is dominated by polls, often with little regard for their veracity (Matthews 2015; Matthews, Pickup, and Cutler 2012). Polls are arguably reported at face value, becoming a large part of the public narrative, making them a legitimate way to identify if a party's support is in decline over time.

Historic polling data are available from Election Almanac (2017a, b, c, and d). If there is indeed a scandal or unpopular previous leader that causes a party's support to drop off precipitously, it is plausible that this would be reflected in these data. Each of the four premiers in question - Dunderdale, Clark, Redford, and Wynne will be addressed in turn. Each figure starts with the election prior to each woman's selection as leader/premier, and continue at least until the next general election. ${ }^{\mathrm{xv}}$

[Figure 1 about here]

Figure 1 suggests the Newfoundland and Labrador PCs started their decline when Danny Williams resigned. Yet, when Dunderdale was selected as leader/premier, the party's support was close to 80 per cent. Clear, though, is that Dunderdale's selection did not stop the party's decline in popularity. Thus, though the party was in decline for most of Dunderdale's tenure as premier, the polls do not suggest that the party's decline was really underway prior to her selection, as would be the case if her selection could be explained by the party being in decline.

[Figure 2 about here]

Figure 2 suggests the context was different for the BC Liberals prior to Christy Clark's selection as leader/premier. Following the general election in October 2011, BC Liberal support appears to decline until Gordon Campbell resigned. At this point, 
the party's vote intention numbers are low enough that it would arguably have lost government in a general election. Yet, the party's support increases during the leadership campaign, and appears to be highest (around 40\%) right around the time Clark is selected as leader/premier. A similar pattern is found for both the Alberta PCs (Figure 3) and the Ontario Liberals (Figure 4), though the increase in the Ontario Liberal Party's support with Wynne's selection is muted, and the estimates of the Alberta PCs's support appear volatile. Where Alberta differs from BC and Ontario is that support for the party in government appears to bottom out well in advance of the previous premier's resignation (Ed Stelmach). However, in BC and Ontario, the party in government's support appears lowest immediately prior to Campbell's and Dalton McGuinty's resignations as party leader and premier. By the time Wynne was selected leader, the Ontario Liberals' support hovered around 30 per cent, suggesting the party would lose government in a general election. By contrast, with their parties polling around 40 per cent when they were selected, the same cannot necessarily be said for Clark or Redford.

[Figures 3 and 4 about here]

Do these public opinion polls confirm that these parties were in decline when they selected women as their leaders/premiers? For Wynne and the Ontario Liberals, the answer is yes. The evidence is less clear, though, for the other parties. Only the Newfoundland and Labrador PCs show consistent, marked decline, and this appears primarily after Dunderdale was selected as leader/premier. Support for the other parties is unfavourable at some point before these women were selected as leader/premier, with the Ontario and BC Liberals polling below 40 per cent at some point, and thus likely to lose if a general election were held then. Notably, in BC, Alberta, and Ontario, party support rebounds after the leadership contest.xvi

Overall, then, the evidence is mixed. By most of these measures, the Ontario Liberals appear to be in decline when Wynne was selected leader. As such, her position was the most precarious, and she fits the literature's expectations about gender, leadership, and parties in decline. By contrast, both Clark and Redford's parties show some signs of stable support and some signs of decline. Polls showed the BC Liberals might lose a general election if were one held before Clark was selected as leader. Yet, all parties were reasonably well financed during this period. In Redford's case, the Alberta PCs had a considerable number of electoral strongholds, suggesting they remained electorally competitive. The evidence for decline for these two parties is weak and mixed at best. There is no evidence to suggest that the Newfoundland and Labrador PCs were in decline when Dunderdale was selected; instead, the party's steady decline after Dunderdale's selection arguably has more to do with the vacuum created by the departure of a popular leader, or with her own leadership failures. ${ }^{\text {xvii }}$

Neither Crisis nor Decline 
Arguably, the crisis/decline narrative cannot explain how Rachel Notley came into the provincial premier's office. Instead, Notley's path fits the most identifiable pattern in the comparative literature on political parties: she was selected to lead a small, left-leaning, electorally uncompetitive party (O'Neill and Stewart, 2009; Cross and Blais, 2012). Even though her party's election to government in the spring of 2015 was unexpected, the context surrounding her selection as party leader is in keeping with the existing generalizations found in the literature.

\section{Discussion and Next Steps}

This article set to out to identify the circumstances under which women have been selected to Canada's premier's offices. The literature suggests that women are most likely to be selected to these positions when their parties are in crisis or decline. Of the women who have served as Canadian premiers, four cases clearly fit this literature: Rita Johnston was selected leader and premier when her party was in crisis, while Pauline Marois was selected leader after her party experienced protracted decline to the point of crisis. The Ontario Liberals were, across multiple indicators, in decline when Kathlene Wynne was selected as leader. And, as leader of a small, left-leaning party, Rachel Notley's selection as leader is the case that best fits the literature. In other words, the comparative literature can explain half of these cases.

What, then, explains the other four premiers? They do not easily fit with the comparative literature investigating women's access to chief political executive offices. Parties selecting women as leaders, especially while in government, are predicted to be in decline. Yet, this cannot readily explain why most of these women were selected simultaneously as party leader and premier. For Callbeck, Dunderdale, Clark, and Redford, the evidence their parties were in decline when they were selected leader is at best partial and inconclusive. Indeed, a critical reader may conclude these parties were not in steady decline when they selected women to the premier's office.

This conclusion is an uneasy counterpoint to conventional wisdom and post-hoc rationalizations. More research is required to assess how robust these findings are beyond this small number of cases, as well as to determine why existing generalizations do not fit these Canadian cases, as well as what these Canadian cases can contribute to the comparative literature. Admittedly, this exploration raises more questions than it answers. If these parties were not in obvious decline by these measures, then what best explains how these women entered the premier's office? Given the short period of time some of these women served as premier, it may be tempting to use ex post facto logic to claim their parties must have been in prior decline. Yet, the evidence presented here does not comport with that post hoc rationalization. It is possible that none of these measures adequately capture a party in decline, though it is perhaps implausible that there is an empirical measure of decline that would capture something by-elections, polls, contributions, and vote and seat changes do not. 
How much of how these women entered the premier's office is about popular prior leaders who define their parties, such as Joe Ghiz in PEI or Danny Williams in Newfoundland and Labrador? Certainly, these parties are not in decline as defined by the literature, but it is also clear that the resignation of popular leaders that arguably defined their parties (and governments) could precipitate a decline in the parties. It is possible, for example, that popular leaders who define their parties purge or otherwise remove competitive men from leadership contests that follow their resignation. Future research could assess this, as well as how much of women's selection as party leader/premier could be explained by leaders who did not necessarily define their parties, such as Ed Stelmach, Dalton McGuinty, or Gordon Campbell.

Future research could also examine how women approach leadership contests, as well as how they lead their parties in election campaigns and in government. It would be particularly interesting to see if the campaign styles of women leading their parties in an election campaign for the first time do so differently if they are in government rather than in opposition. The role of caucus and other internal party organizations may be particularly important, as negative reactions to leadership styles are highlighted as reasons why some women face (gendered) caucus revolts (CBC News, 2014).

It would be interesting to see how context in which women are selected affects their leadership and government styles, as well as their exits from office. Certainly, the context in which some women enter party leadership roles structure how they leave it (O'Brien, 2015; O'Neill and Stewart, 2009). The same is arguably true for women premiers. This study demonstrates that some women become leader/premier when their parties do not appear, at least by these indicators, to be in decline. Given this, it is surprising that their tenure in the premier's office is comparatively short.xviii Generally speaking, in parliamentary democracies, party leaders' tenure averages somewhere between 2 and 10 years (Cross and Blais, 2012). When all Canadian party leaders are considered, the average tenure does not appear to be conditioned by leader gender. That said, women heading major parties had considerably shorter terms as leader (2.4 years) than did their male peers (5.3 years, see 0'Neill and Stewart, 2009). Women in the premier's office are, to date, little different from women heading major parties: on average, their tenure is about 31 months, or about 2.5 years (see Table 1 ).

Studies could also investigate the roll of the media; preliminary findings suggest that women premiers receive about as much coverage as do men (Thomas, Harell, and Gosselin forthcoming). Women premiers may still receive different coverage compared to their male peers, both during election campaigns and during their time in government. A content analysis of media reports of polls may shine new light on the context when women are selected as party leaders/premiers, as well as when, as premiers, they make an early exit from the office. 
Finally, the Canadian territories offer a unique context to study the effect of institutions on women premiers. Two women led 'consensus governments'; Northern women's educational attainment and active recruitment into territorial public services act to reduce the structural barriers to women's involvement in politics, though important cultural barriers remain (White, 2013). All representatives elected to the legislatures in the Northwest Territories and Nunavut are independents without party ties, and the premier is selected from among their members. This divorces the chief executive from political parties, while also allowing us to test hypotheses that contend that women are more likely than men to prefer consensus over contentious politics. Studies investigating institutional effects must note that chief executives in the territories are not as powerful as their provincial counterparts, as consensus government constrains those premiers in very different ways than their southern counterparts. Importantly, both of the territorial legislatures that govern through consensus - the Northwest Territories and Nunavut - have selected women premiers who served a single term.

Ultimately, the goal of the study is to explain if women premiers were by parties that were in crisis or decline. Indeed, because half of the cases cannot yet be easily explained, gender and Canada's provincial premier's offices are a fruitful area for future investigation, for scholars of Canadian and comparative politics alike. 


\section{References}

2006 Electoral Districts Boundaries Commission. 2014. "Reports." http://www.justice.gov.nl.ca/ebc/reports.htm. Accessed 30 March 2014.

Bashevkin, Sylvia. 1993. Toeing the Lines: Women and Party Politics in English Canada. Toronto: Oxford University Press.

Bashevkin, Sylvia. 2009. Women, Power, Politics: The Hidden Story of Canada's Unfinished Democracy. Toronto: Oxford University Press.

Beckwith, Karen. 2015. "Before Prime Minister: Margaret Thatcher, Angela Merkel, and Gendered Party Leadership Contests." Politics \& Gender 11(2015): 718745.

Bodet, Marc André. 2013. "Strongholds and Battlegrounds: Measuring Party Support Stability in Canada." Canadian Journal of Political Science 46(3): 575-596.

Bruckmüller, Susanne, and Nyla E. Branscombe. 2010. "The Glass Cliff: When and Why Women Are Selected as Leaders in Crisis Contexts." British Journal of Social Psychology 49: 433-451.

CBC Digital Archives. 2014. "B.C. Elections: Bill Vander Zalm resigns." http://www.cbc.ca/archives/categories/politics/provincial-territorialpolitics/how-the-west-is-won-bc-elections-1952-2005/bill-vander-zalmresigns.html. Accessed 1 April 2014.

CBC News. 2007. "Marois officially enters PQ leadership race." www.cbc.ca/news/canada/marois-officially-enters-pq-leadership-race1.691297. Accessed 29 March 2014

CBC News. 2014. "Calgary MLA Len Webber quits Tory caucus to protest premier." http://www.cbc.ca/news/canada/calgary/calgary-mla-len-webber-quitstory-caucus-to-protest-premier-1.2570893. Accessed 1 April 2014.

Coletto, David, Harold J. Jansen, and Lisa Young. 2011. "Stratarchical Party Organization and Party Finance in Canada." Canadian Journal of Political Science 44(1): 111-136.

Cross, William. 2004. Political Parties, The Canadian Democratic Audit. Vancouver: UBC Press.

Cross, William, and André Blais. 2012. Politics at the Centre: The Selection and Removal of Party Leaders in Anglo Parliamentary Democracies. Oxford: Oxford University Press.

Election Almanac. 2017a. "Historic Alberta Election Polls." http://www.electionalmanac.com/ea/alberta-election-polls/. Accessed 10 January 2017.

Election Almanac. 2017b. "Historic British Columbia Election Polls." http://www.electionalmanac.com/ea/british-columbia-election-polls/. Accessed 10 January 2017. Accessed 22 August 2015.

Election Almanac. 2017c. "Historic Nfld. \& Labrador Election Polls." http://www.electionalmanac.com/ea/newfoundland-labrador-electionpolls/. Accessed 10 January 2017.

Election Almanac. 2017d "Historic Ontario Election Polls." http://www.electionalmanac.com/ea/ontario-election-polls/. Accessed 10 January 2017. 
Elections Alberta. 2013. "Electoral Boundaries Commissions Act." http://www.elections.ab.ca/Public\%20Website/575.htm. Accessed 30 March 2014.

Elections Alberta. 2014. "Financial Disclosure, Financial Period - Annual." http://efpublic.elections.ab.ca/efEvents.cfm?MID=FE A. Accessed 30 March 2014.

Elections BC. 2014. "Financial Reports and Political Contributions System." http://contributions.electionsbc.gov.bc.ca/pcs/ Accessed 1 April 2014.

Elections BC. 2014. "Provincial General Elections - Results." http://www.elections.bc.ca/index.php/resource-centre/reports/\#ge Accessed 1 April 2014.

Elections BC. 2014b. "Electoral Boundaries Commissions Reports." http://www.elections.bc.ca/index.php/maps/electoral-boundariescommission-reports/. Accessed 30 March 2014.

Elections Newfoundland and Labrador. 2015. "Political Finance Reports: Income and Expenditure Statements." Accessed 30 March 2014. http://www.elections.gov.nl.ca/elections/PoliticalFinanceReports/index.asp

Elections Ontario. 2016. "Yearly Financial Statements." http://www.elections.on.ca/en/political-entities-in-ontario/financialstatements/yearly-financial-statements.html Accessed 30 March 2014.

Elections Prince Edward Island. 2011. "A Brief History of Electoral Reform on Prince Edward Island." http://www.electionspei.ca/index.php?number=1055620\&lang=E Accessed 8 November 2017.

Fox, Richard L., and Zoe M. Oxley. 2003. "Gender Stereotyping in State Executive Elections: Candidate Selection and Success." Journal of Politics 65(3): 833850.

Franks, C.E.S. 1987. The Parliament of Canada. Toronto: University of Toronto Press. Fridkin Khan, Kim. 1994. “Does Gender Make a Difference? An Experimental Examination of Sex Stereotypes and Press Patterns in Statewide Campaigns." American Journal of Political Science 38(1): 162-195.

Gidengil, Elisabeth, Neil Nevitte, André Blais, Joanna Everitt, and Patrick Fournier. 2012. Dominance and Decline: Making Sense of Recent Canadian Elections. Toronto: University of Toronto Press.

Government of Canada. 2017. "Provinces and Territories." https://www.canada.ca/en/intergovernmental-affairs/services/provincesterritories.html. Accessed 28 September 2017.

Grénier, Éric. 2013. "B.C. post-mortem, polling methodologies, and where to go from here." http://www.threehundredeight.com/2013/05/bc-post-mortempolling-methodologies.html. Accessed 30 March 2014.

Grénier, Éric. 2012a. "Quebec election: expectations vs. results." http://www.threehundredeight.com/2012/09/quebec-electionexpectations-vs-results.html. Accessed 30 March 2014.

Grénier, Éric. 2012b. "Alberta election aftermath." http://www.threehundredeight.com/2012/04/alberta-electionaftermath.html. Accessed 30 March 2014. 
Huddy, Leonie, and Nayda Terkildsen. 1993. "The Consequences of Gender Stereotypes for Women Candidates at Different Levels and Types of Office." Political Research Quarterly 46(3): 503-525.

Huddy, Leonie, and Theresa Capelos. 2002. "The Impact of Gender Stereotypes on Voters' Assessment of Women Candidates." In Social Psychological Applications to Social Issues: Developments in Political Pscyhology ed. Victor Ottai. New York: Kluwer Academic/Plenum.

Jalalzai, Farida. 2013. Shattered, Cracked, or Firmly Intact? Women and the Executive Glass Ceiling Worldwide. New York: Oxford University Press.

Jalalzai, Farida. 2008. "Women Rule: Shattering the Executive Glass Ceiling." Politics \& Gender 4(2): 205-231.

Kathlene, Lyn. 1994. "Power and Influence in State Legislative Policymaking: The Interaction of Gender and Position in Committee Hearing Debates." The American Political Science Review 88(3): 560-576.

Le Directeur Général des Élections du Québec. 2014. "General Elections." http://www.electionsquebec.qc.ca/english/provincial/electionresults/general-elections.php?e=3\#e. Accessed 30 March 2014.

Loewen, Peter and Frédérick Bastien. 2010. "(In)Significant Elections? Federal Byelections in Canada, 1963-2008." Canadian Journal of Political Science 43(1): 87-105.

McElroy, Justin. 2017. "Grace McCarthy, influential B.C. cabinet minister for 3 decades, has died at 89." CBC News http://www.cbc.ca/news/canada/british-columbia/grace-mccarthy-obit1.3987119. Accessed 28 September 2017.

Mercier, Noémi. 2012. "Pauline Marois: l'étoffe d'un premier ministre?" L'actualité. Montreal 29-44. http://www.lactualite.com/actualites/politique/paulinemarois-letoffe-dun-premier-ministre/. Accessed 29 March 2014.

O’Brien, Diana Z. 2015. "Rising to the Top: Gender, Political Performance, and Party Leadership in Parliamentary Democracies." American Journal of Political Science DOI: 10.1111/ajps.12173.

O’Brien, Diana Z., Matthew Mendez, Jordan Carr Peterson, and Jihyun Shin. 2015. "Letting Down the Ladder or Shutting the Dorr: Female Prime Ministers, Party Leaders, and Cabinet Ministers." Politics \& Gender 11(2015): 689-717.

O'Neill, Brenda, and David K. Stewart. 2009. "Gender and Political Party Leadership in Canada." Party Politics 15(6): 737-757.

Paikin, Steve. 2003. The Dark Side: The Personal Price of a Political Life. Toronto: Viking Canada.

Pickup, Mark, J. Scott Matthews Will Jennings, Robert Ford and Stephen Fisher. 2011. "Why did the polls overestimate Liberal Democratic Support? Sources of Polling Error in the 2010 British General Election." Journal of Elections Public Opinion and Parties 21(2): 179-209.

Pickup, Mark and Richard Johnston. 2008. "Campaign Trial Heats as Election Forecasts: Evidence from the 2004 Presidential Campaign Polls." International Journal of Forecasting 24(2): 272-284.

Poguntke, Thomas and Paul Webb, eds. 2005. The Presidentialization of Politics: A Comparative Study of Modern Democracies. Oxford: Oxford University Press. 
Russell, Peter H. 2008. Two Cheers for Minority Government: The Evolution of Canadian Parliamentary Democracy. Toronto: Emond Montgomery Publications.

Ryan, Michelle K., Alexander Haslam, and Clara Kulich. 2010. "Politics and the Glass Cliff: Evidence That Women Are Preferentially Selected to Contest Hard-toWin Seats." Psychology of Women Quarterly 34: 56-64.

Savoie, Donald. 1999. Governing from the Centre: The Concentration of Power in Canadian Politics. Toronto: University of Toronto Press.

Savoie, Donald. 2003. Breaking the Bargain: Public Servants, Ministers, and Parliament. Toronto: University of Toronto Press.

Scarrow, Susan E. 2007. "Political Finance in Comparative Perspective." Annual Review of Political Science. 10: 193-210.

Simeon, Richard. 2002. "Federalism and Decentralization in Canada." Paper presented at the $2^{\text {nd }}$ International Conference on Decentralization, Manila.

Stewart, David K. and R.K. Carty. 1993. "Does Changing the Party Leader Provide an Electoral Boost? A Study of Canadian Provincial Parties: 1960-1992.” Canadian Journal of Political Science 26(2): 313-330.

Streb, Matthew J., Barbara Burrell, Brian Frederick, and Michael A. Genovese. 2008. "Social Desirability Effects and Support for a Female American President." Public Opinion Quarterly 72(1): 76-89.

Studlar, Donley T., and Gary F. Moncrief. 1997. "The Recruitment of Women Cabinet Ministers in the Canadian Provinces." Governance 10(1): 67-81.

Thomas, Melanee, and Marc André Bodet. 2013. "Sacrificial Lambs, Women Candidates, and District Competitiveness in Canada." Electoral Studies 32(1): 153-166.

Thomas, Melanee, Allison Harell, and Tania Gosselin. Forthcoming. "Gender, Tone, and Content of Premiers' News Coverage: A Matched Comparison." In Polticial Elites in Canada: Power and Influence in Instantaneous Times, eds. Alex Marland, Andrea Lawlor, and Thierry Giasson. Vancouver: UBC Press.

Trimble, Linda, and Jane Arscott. 2003. Still Counting: Women in Politics across Canada. Peterborough, ON: Broadview Press.

Trimble, Linda, Jane Arscott, and Manon Tremblay. 2014. "A Few More Women.” In Stalled: The Representation of Women in Canadian Governments. Vancouver: UBC Press.

Webb, Paul and Thomas Poguntke. 2013. "The Presidentialisation of Politics Thesis Defended." Parliamentary Affairs 66: 646-654.

White, Graham. 2005. Cabinets and First Ministers. Vancouver: UBC Press.

White, Graham. 2013. "In the Presence of Northern Aboriginal Women? Women in Territorial Politics." In Stalled: The Representation of Women in Canadian Governments, eds Linda Trimble, Jane Arscott, and Manon Tremblay. Vancover: UBC Press.

i This is sometimes referred to the glass cliff (Ryan and Haslam, 2007; Bruckmüler and Branscombe, 2010). The "glass cliff" metaphor is a take on the "glass ceiling", where women can see higher positions, but are unable to access them due to invisible, enduring barriers. While the glass ceiling is an effective metaphor, the glass cliff arguably is not, as it suggests that women are unaware of their 
own precarious position, and/or that they are not strategic actors, easily pushed over a cliff by others.

ii Note, though, that this study does not address territorial premiers. Territories differ from provinces both in their constitutionally defined powers and, for those territories that use it, the nature of consensus government.

iii Half of the women listed in Table 1 are both the first women to serve as both premier of their province and leader of their party - Rita Johnston in British Columbia (BC, Social Credit), Catherine Callbeck on PEI (Liberal), Alison Redford in Alberta (Progressive Conservative or PC), and Pauline Marois in Québec (Parti Québécois or PQ). Another two are the first women to serve as premier in their respective provinces - Kathy Dunderdale (PC) and Kathleen Wynne (Liberal) - but the second women to serve as their party's leader. Christy Clark is the second woman to lead her party and her province as premier, while Rachel Notley is the first woman to lead her party (New Democratic Party of Alberta, or NDP), but the second woman to hold the premier's office in her province. With Notley's selection as premier, Alberta became the first and only Canadian province to select a party led by a woman to government twice, two elections in row. At the federal level, Kim Campbell remains the only woman to led a governing party.

iv 1991 is selected as it is the first year a woman is sworn in as premier of a province in Canada (see Table 1).

v Two of the women in this study were acclaimed (Marois, Dunderdale). The others faced between 2 and 5 male competitors. In at least two of these contests (Alberta, Ontario), men in the contest could arguably be seen as the preferred candidates of their parties' establishments. This is not incompatible with the comparative literature (see Beckwith, 2015, particularly with respect to the presented narrative regarding Thatcher).

vi Redistricting took place in BC in 2008, straddling the two elections prior to Christy Clark's being selected leader of the BC Liberal Party (Elections BC, 2014b). Similarly, redistricting took place in Newfoundland and Labrador in 2006, in between the two prior general elections (2003 and 2007) held before Dunderdale's selection in 2010 (2006 Electoral Boundaries Commission, 2014).

vii Elections PEI (2011) reports that though district boundaries were stable in PEI prior to the 1996 general election, earlier elections were conducted using multi-member districts; this is also the case in British Columbia prior to Johnston's selection as premier.

viii Public opinion poll data are drawn from the lists available from www.electionalmanac.com. ix Certainly, there are documented issues with polls in Alberta, Quebec, and BC to suggest that these data may not accurately reflect whether a party's support is genuinely in decline (see Grénier, 2013; 2012a; 2012b; see also Pickup and Johnston, 2008; Pickup et al., 2011).

x Marois sought the leadership of the Parti Québécois (PQ) three times. She first ran in 1984 after René Lévesque resigned. She ran again after the PQ's electoral loss in 2003 (Mercier, 2012). She finished second in both contests.

xi Gilles Duceppe, the popular leader of the Bloc Québécois (BQ), mused that he would seek the leadership of the PQ, but quickly withdrew his name from contention (CBC News, 2007).

xii The data required to build the three of five indicators of decline are not available for PEI for the time leading up to Callbeck's selection. As noted above, PEI used dual member districts up to 1993; this makes it impossible to build Bodet's strongholds and battlegrounds measure. Similarly, neither contributions data nor public opinion polls are available for the period in question. Only previous election results and by-election victories are presented here.

xiii Marois and Notley are omitted from Table 2 as they were first selected premier through general election.

xiv One hypothesis for the Ontario Liberals' decline is that their unpopularity rested with their length of time in office prior to Wynne's selection. Though plausible, this pattern does not appear to be immediately confirmed in other provinces. The Ontario and BC Liberals both held office for about 10 years before selecting women as leader/premier; this compares to 7 years for the PEI Liberals and Newfoundland PCs, 16 years for the BC Social Credit, and 40 years for the Alberta PCs. Thus, while length of time in government is a potentially important contextual factor, it is one of several that could be considered in future studies.

xv Figures 1-4 are generated using lowess regression models with a 0.25 bandwidth. 
xvi Conventional wisdom may assume that parties get a polling boost after selecting a new leader. However, research shows that while a party may get a boost at the next election after selecting a new leader by leadership convention, this is not necessarily the case immediately at the polls (Stewart and Carty, 1993: 318). New research is required to assess if this conclusion still holds.

xvii Catherine Callbeck is also an awkward fit with Beckwith's (2015) framework. She was selected leader of the PEI Liberal Party in 1991, and led it to a majority election victory later that year. Joe Ghiz's resignation created this opportunity for Callbeck. Ghiz was a popular leader, having led the party since 1981. Though the party lost a moderate amount of the popular vote in 1993 (see Table 1), its popularity remained significant enough that, though possible, it is implausible that the party was in decline when Callbeck was selected leader/premier. Instead, it may be more plausible to see Callbeck and Dunderdale as paired cases, taking over parties defined by popular leaders.

xviii Two avenues for future research also stem from these observations. First, an update to O'Neill and Stewart (2009) might be illuminating, particularly if it confirms that women's path to competitive party leadership is different from men's beyond these cases. Second, it is possible that the reason why some of these women won majority re-election is due to their considerable political skills, as well as those of their campaign teams. Future projects could ask how women (and men) craft backrooms and/or campaign and advisory teams. 